\title{
The effect of lipopolysaccharide of Pseudomonas syringae pv. atrofaciens 9417 on mutagenicity in pro- and eukaryotic systems
}

\author{
Yu. M. Bogdan, L. M. Butsenko, L. A. Pasichnyk, R. I. Gvozdyak
}

Danylo Zabolotny Institute of Microbiology and Virology, NAS of Ukraine

154, Academician Zabolotny Str., Kyiv, 03680 Ukraine

bogdan.julia@gmail.com

\begin{abstract}
Aim. To study the effect of lipopolysaccharide (LPS) of Pseudomonas syringae pv. atrofaciens on spontaneous and induced mutations in pro- and eukaryotic test-systems. Methods. Mutagenic and antimutagenic properties of LPS were studied in Allium cepa-test and Ames test. Results. LPS does not influence the spontaneous mutations of Salmonella typhimurium and decreases the level of mutations induced by potassium dichromate and $N$-methyl- $N^{\prime}$-nitro- $N$ '-nitrosoguanidine. LPS reduces a mitotic index at concentrations of 10.0 and $5.0 \mathrm{mg} / \mathrm{ml}$ and increases the number of chromosomes' fragments in cells of A. cepa root apical meristem at concentrations of 5.0 and $2.5 \mathrm{mg} / \mathrm{ml}$. Conclusion. Different effect of LPS on mutagenesis in pro- and eukaryotic cells has been established. LPS revealed mutagenic properties in A. cepa-test and antimutagenic properties in Ames test.
\end{abstract}

Keywords: mutations, chromosome aberrations, LPS.

Introduction. Biopolymers of cell surface play an important role in processes of interaction of gram-negative bacteria and macroorganisms. In particular, lipopolysaccharides (LPS) induce defence reactions and formation of a series of mediators in [the] host organism, participate in processes of infection, pathogenicity and symbiosis, as well as in processes of colonization and formation of microenvironment.

At present, the impact of LPS of some bacteria on human and animal cells has been studied well enough. On the contrary, insufficient attention is paid to the affect of this biopolymer of phytopathogenic bacteria on plant cells. Previous treatment of plants with LPS preparations is known to prevent hypersensitive response in tobacco

(C) Institute of Molecular Biology and Genetics NAS of Ukraine, 2010 leaves [1-3]. The inhibition of hypersensitive response is supposed to reflect [the] LPS-mediated mechanism of facilitating pathogenesis during natural infection. For instance, treatment of roots of white clover with LPS preparation, isolated from cells of Rhizobium leguminosarum bacteria, facilitates the formation of infection threads during the next injection of suspension of intact cells of these bacteria [2].

On the other hand, there is an opinion that LPS increase plant resistance to phytopathogenic bacteria and are one of the components, related to induced systemic resistance of plants to pathogens [4]. In particular, LPS mediate the induction of helio-dependent, long-term and systemic phases of resistance of tobacco leaves. These processes are conditioned by the formation of antimicrobial 
substances in plants [2]. The capability of bacteria to induce defence reactions in plants is related to specific LPS constituents. For instance, lipid A induces defence reactions in plants, while O-specific polysaccharide and core oligosaccharide do not demonstrate such activity [2].

Regardless some steps in the investigation of LPS interaction with plant cells, one of the aspects of this interaction - namely, the capability of these macromolecules to cause changes in genetic material of plants - is yet to be studied. Previously, we have proven [the] antimutagenic activity of LPS of $P$. syringae pv. syringae UKM B-1027, P. syringae pv. atrofaciens $8281, P$. syringae pv. atrofaciens 9400 and $P$. syringae pv. coronafaciens 9030 in the prokaryotic test-system [5-8]. However, an impact of LPS of phytopathogenic bacteria on the genome of plants is still unknown. Therefore, the aim of our work was to study the impact of LPS of P. syringae pv. atrofaciens 9417 on the frequency of chromosome aberrations in Allium сера and on spontaneous and induced mutations of bacteria in [the] Ames test.

Materials and Methods. LPS preparation of P. syringae pv. atrofaciens 9417 was used in the work. The strain of $P$. syringae pv. atrofaciens 9417 was isolated from infected tissues of spring wheat, Rannya 93 cultivar. LPS preparation was obtained by extraction with $0.85 \%$ solution of sodium chloride from raw biomass of bacteria cells and dialysis against distilled water [9]. The obtained biopolymer preparation was purified by ultracentrifugation at $105,000 \mathrm{~g}$ in cold $\left(4^{\circ} \mathrm{C}\right)$ for 4 hours and lyophilically dried.

Mutagenic and antimutagenic activity of LPS 9417 was defined in [the] standard semiquantitative Ames test in the doses from 1000.0 up to $0.1 \mu \mathrm{g}$ per plate [10]. Two strains of Salmonella typhimurium were used for this purpose: TA98 and TA100. $0.25 \mathrm{ml}$ of specially prepared suspension of $S$. typhimurium cells with optic density of $\mathrm{D}_{0.7}-\mathrm{D}_{0.8}$ and wavelength of $540 \mathrm{~nm}$ was applied to each plate with the addition of $0.1 \mathrm{ml}$ of corresponding solution of the investigated substance. After cultivation at $37^{\circ} \mathrm{C}$ for 48 hours the number of $\mathrm{His}^{+}$-revertants colonies was calculated.

$200 \mu \mathrm{g}$ of potassium dichromate per plate [11] and

$2 \mu \mathrm{g}$ of $\mathrm{N}$-methyl-N'-nitro-N'-nitrosoguanidine
(MNNG) per plate [12] were used as [a] positive mutagen. LPS 9417 was introduced in doses of $0.1-1,000 \mu \mathrm{g}$ per plate. The decrease in the number of induced mutations $(X)$ was determined using the following formula (\%):

$$
X=100 \%-\frac{X_{\mathrm{e}}-X_{\mathrm{sbm}}}{X_{\mathrm{pc}}-X_{\mathrm{sbm}}} \cdot 100 \%,
$$

where $X_{e}$ is the number of colonies in the experiments; $X_{p c}$ is the number of colonies in positive control; $X_{s b m}$ is spontaneous background of mutations.

The presence of statistically significant differences between the number of colonies of His -revertants in the experiment and spontaneous background of mutations was evaluated using Student's $t$-test $(\mathrm{p}=0.05)$.

Among plant test-systems for mutagenicity we selected modified A. cepa-test [13], as it is one of the simplest and most frequently used in the study on mutagenicity of various substances. The seeds of onion (A. cepa), Khaltsedon cultivar, were used in the work. LPS phytotoxicity was determined on sprouts of onion seeds in LPS solutions with concentrations of 10.0; 5.0; $1.0 ; 0.1 ; 0.01$ and $0.001 \mathrm{mg} / \mathrm{ml}$ [13]. After growing for 96 hours the length of each root was measured and the dependence between LPS concentration and the length of roots was defined in per cent from the control. The concentration, at which there was $50 \%$ decrease in the length of roots compared to the control $\left(\mathrm{EC}_{50}\right)$, was obtained on a chart in logarithmic scale by interpolation method.

Cytogenetic investigations were performed at the following LPS concentrations: $\mathrm{EC}_{50}$ and 50, 25, and $10 \%$ from $\mathrm{EC}_{50}$ index [13]. A. cepa seeds were consecutively grown in distilled water for 48 and 24 hours in LPS solution. Onion roots were fixated in ethanol:[-]acetic acid mixture (3:1) and stained with $1 \%$ orcein stain in acetic acid. Cytogenetic analysis was conducted on temporary slides of root apical meristem. The number of ana-telophases with chromosome aberrations (fragments and bridges) and undamaged chromosomes was determined. In each variant of the experiment we analyzed 10 roots of $A$. cepa and at least 100 ana-telophases. [A] Statistical analysis of the data was performed using ANOVA test in Statistica 5.0 programme [14]. 
Table 1

The effect of LPS of P. syringae pv. atrofaciens 9417 on the number of spontaneous mutations in test-strains of S. typhimurium

\begin{tabular}{c|c|c}
\hline Test-strain & $\begin{array}{c}\text { Dose of LPS, } \\
\mu \text { g per plate }\end{array}$ & $\begin{array}{c}\text { Number of colonies } \\
\text { of Hist-revertants } \\
\text { per plate }\end{array}$ \\
\hline TA98 & 1000,0 & $53 \pm 14$ \\
100,0 & $46 \pm 10$ \\
10,0 & $49 \pm 9$ \\
1,0 & $58 \pm 5$ \\
TA100 & 0,1 & $51 \pm 2$ \\
& 1000,0 & $64 \pm 4$ \\
& 100,0 & $88 \pm 12$ \\
10,0 & $76 \pm 12$ \\
& 1,0 & $72 \pm 2$ \\
& 0,1 & $66 \pm 8$ \\
\hline
\end{tabular}

N o t e. Spontaneous background of mutations for $S$. typhimurium TA98 and TA100 is $54 \pm 9$ and $83 \pm 5$, respectively
Results and Discussion. LPS of $P$. syringae pv. atrofaciens 9417 do not affect the number of spontaneous mutations in test-strains of S. typhimurium (Table 1). In particular, the introduction of LPS in doses of $1,000.0$ to $0.1 \mu \mathrm{g}$ per plate results in about 46-58 colonies of His $^{+}$-revertants of $S$. typhimurium TA98 per plate which does not show statistically significant differences from spontaneous background of mutations $(54 \pm 9)$. Similar results were obtained in the experiment with $S$. typhimurium TA100. The introduction of LPS results in about 64-88 colonies of $\mathrm{His}^{+}$-revertants per plate which does not differ much from spontaneous background of mutations ( $83 \pm 5$ ).

On the contrary, LPS of $P$. syringae pv. atrofaciens 9417 demonstrates antimutagenic activity in Ames test related to [the] mutations, induced by potassium dichromate and MNNG. The introduction of these LPS in the doses of 1,000.0 and $100.0 \mu \mathrm{g}$ per plate decreases mutations of $S$. typhimurium TA98,
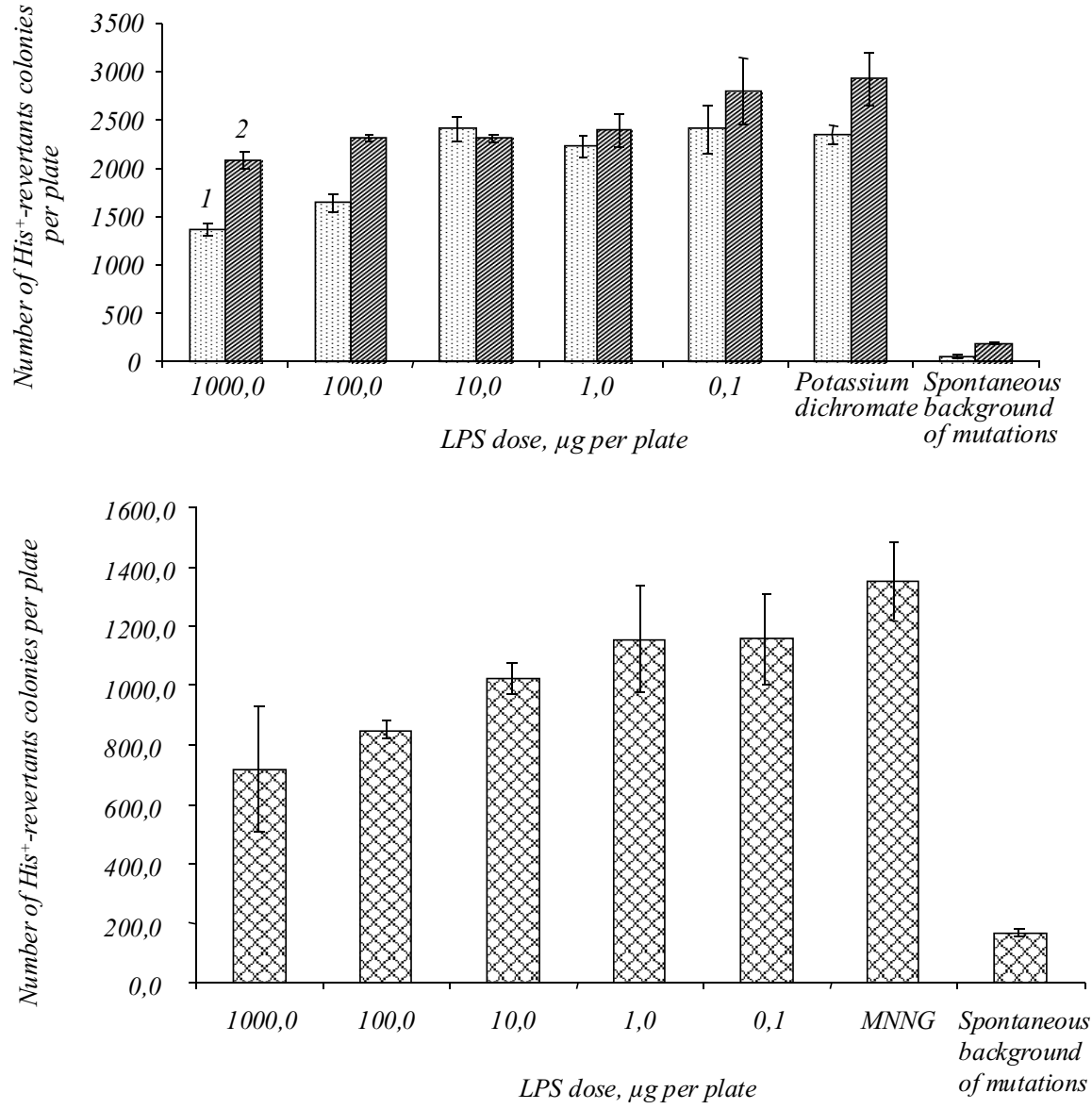

Fig.1. The effect of preparation of LPS of $P$. syringae pv. atrofaciens 9417 on mutations in test-strains of S. typhimurium TA98 (1) and TA100 (2), induced by potassium dichromate (200 $\mu \mathrm{g}$ per plate)
Fig. 2. The effect of preparation of LPS of $P$. syringae pv. atrofaciens 9417 on mutations in test-strains of $S$. typhimurium TA100, induced by MNNG ( $2 \mu \mathrm{g}$ per plate) 


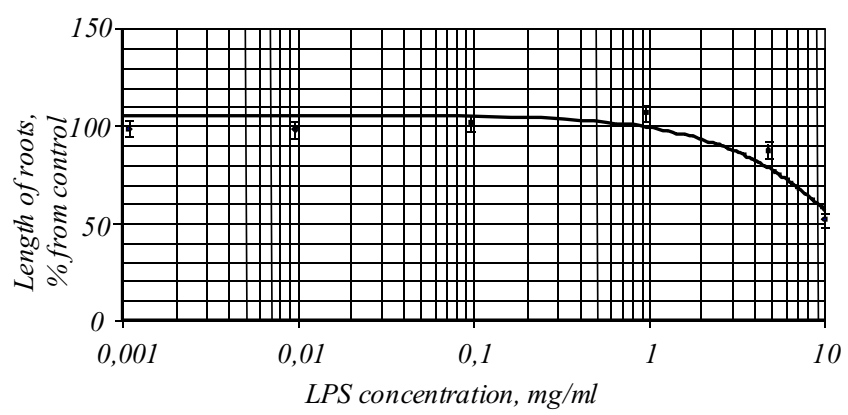

Fig.3 The effect of LPS of $P$. syringae pv. atrofaciens 9417 on the growth of $A$. cepa roots length increases by $9.6 \%$. The introduction of the biopolymers in concentrations of $0.1 ; 0.01$ and 0.001 $\mathrm{mg} / \mathrm{ml}$ does not demonstrate any impact on the growth of onion roots. Contrary to previously studied LPS preparation of $P$. syringae pv. atrofaciens 9400 [15], LPS of $P$. syringae pv. atrofaciens 9417 stimulated the growth of roots in a higher concentration -1.0 $\mathrm{mg} / \mathrm{ml}$, while the mentioned strain 9400 demonstrated the stimulating effect pertaining to the growth of roots by $20-30 \%$ in concentrations of $0.1 ; 0.01$ and $0.001 \mathrm{mg} / \mathrm{ml}$. It may be assumed that differences in

Table 2

Number of aberrant ana-telophases and mitotic activity in apical meristem of A. cepa at the effect of LPS of P. syringae pv. atrofaciens

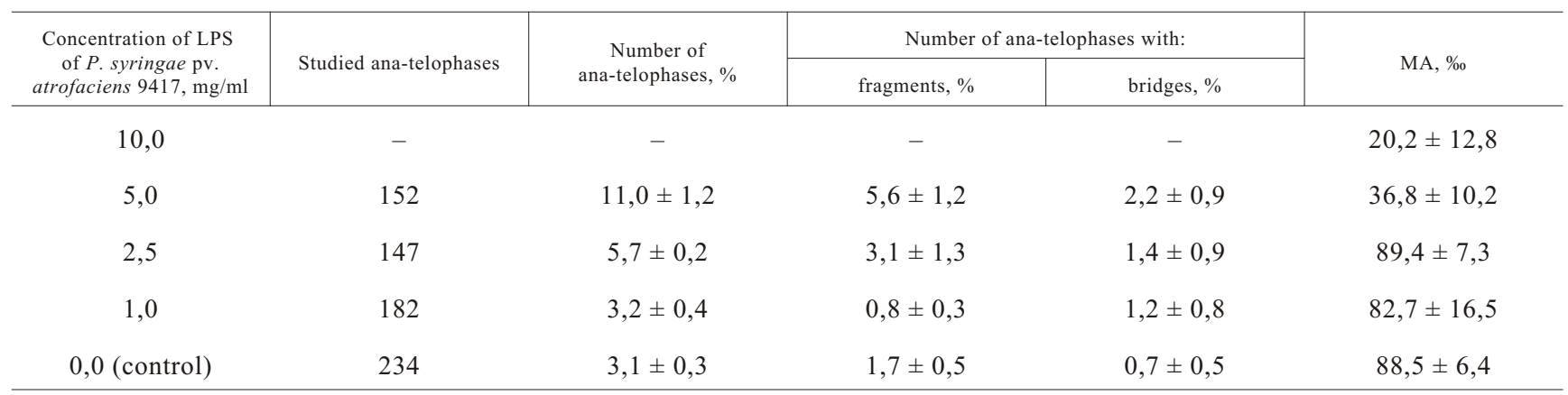

N o t e. "-" - not analysed

induced by potassium dichromate, by 43 and $30 \%$, respectively, and mutations of $S$. typhimurium TA100 by 26 and $18 \%$, respectively. Besides, [the dose of] $10.0 \mu \mathrm{g}$ of LPS P. syringae pv. atrofaciens 9417 per plate also decrease[s] mutagenesis, induced by potassium dichromate, by $17 \%$ (Fig. 1).

The introduction of LPS of $P$. syringae $\mathrm{pv}$. atrofaciens 9417 in concentrations of 1,000.0; 100.0 and $10.0 \mu \mathrm{g}$ per plate results in the decrease of mutations of test-strain $S$. typhimurium TA100, induced by MNNG, by 46, 33, and $16 \%$, respectively, while the doses of 1.0 and $0.1 \mu \mathrm{g}$ do not affect the number of induced mutations (Fig. 2).

LPS of $P$. syringae pv. atrofaciens 9417 are phytotoxic for $A$. серa only in high concentrations (Fig. 3). Thus, due to the impact of these biopolymers in the doses of $10.0 \mathrm{mg} / \mathrm{ml}$ and $5.0 \mathrm{mg} / \mathrm{ml}$, the growth of onion roots decreases by $48.2 \%$ and $8.2 \%$, respectively. LPS in the concentration of $1.0 \mathrm{mg} / \mathrm{ml}$ is a weak stimulus for the growth of $A$. cepa roots - their the effects of LPS preparations of these two strains are related to the structure specificity of the mentioned biopolymer in different strains.

LPS of $P$. syringae pv. atrofaciens 9417 in concentrations of 10.0 and $5.0 \mathrm{mg} / \mathrm{ml}$ decrease mitotic activity by 68.2 and $51.7 \%$, respectively (Table 2 ) and are inactive in concentrations of 2.5 and $1.0 \mathrm{mg} / \mathrm{ml}$. Therefore, only high concentrations of the mentioned LPS inhibit the division of plant cells.

In high doses [of] LPS of $P$. syringae $\mathrm{pv}$. atrofaciens 9417 increase the frequency of chromosome aberrations in the cells of root apical meristem of onions (Table 2). Thus, the introduction of LPS of $P$. syringae pv. atrofaciens 9417 in concentrations of 5.0 and $2.5 \mathrm{mg} / \mathrm{ml}$ results in the increase in the frequency of chromosome aberrations by 3.5 and 1.8 times, respectively, compared to the control. LPS preparation in the concentration of 1.0 $\mathrm{mg} / \mathrm{ml}$ does not influence the frequency of chromosome aberrations. 
The most common aberrations in the cells of onion roots are fragments. The introduction of LPS of P. syringae pv. atrofaciens 9417 in concentrations of 5.0 and $2.5 \mathrm{mg} / \mathrm{ml}$ results in 5.6 and $3.1 \%$ of fragments, respectively. In case of application of LPS concentration of $1.0 \mathrm{mg} / \mathrm{ml}$ and [in] the control variant of the experiment, this index was 0.8 and $1.7 \%$, respectively. At the same time, there were no statistically significant differences in the number of bridges from the control index in all the variants of the experiment, ranging from 0.7 to $2.2 \%$.

LPS, used by us, increase the frequency of chromosome aberrations only in concentration of over $2.5 \mathrm{mg} / \mathrm{ml}$ similar to LPS of $P$. syringae $\mathrm{pv}$. atrofaciens 9400 , studied by us previously [15]. At the same time, LPS 9417 demonstrate somewhat weaker mutagenic effect compared to LPS of $P$. syringae pv. atrofaciens 9400 . For instance, LPS of $P$. syringae pv. atrofaciens 9400 in doses of 5.0 and $2.5 \mathrm{mg} / \mathrm{ml}$ cause increase in aberrant cells to 16.4 and $13.4 \%$, respectively [15], which is 5.4 and $7.7 \%$ higher than similar indices for LPS of $P$. syringae pv. atrofaciens 9417.

Thus, similar to previously investigated LPS of $P$. syringae pv. atrofaciens 9400 , LPS of $P$. syringae pv. atrofaciens 9417 demonstrate mutagenic activity pertaining to plants. The same feature of LPS of gram-negative bacteria was observed in case of influencing cells of humans and animals. For instance, it was revealed that LPS of Escherichia coli may increase the number of aberrant metaphases in the culture of human blood cells in the doses of 25 and 100 $\mu \mathrm{g} / \mathrm{ml}$ [16]. Moreover, LPS are capable of demonstrating genotoxic activity towards blood cells and bone marrow cells of rats on condition of biopolymer injection in the dose of $10 \mathrm{mg} / \mathrm{kg}$ [17].

Probably, the capability of causing mutations in eukaryotic cells under division is inherent in all LPS. However, the issue of mechanisms and specificity of the activity of LPS, isolated from different kinds of gram-negative bacteria, pertaining to eukaryotic cells, is yet to be determined. It is known that the induction of mutations in the cells of humans and animals with the participation of LPS is connected to oxidative stress [18]. It is possible that similar processes occur when LPS influences plant cells. However, literature data on the capability of these biopolymers to increase oxygen radical content in plants are rather contradictory [2].

The capability of LPS to decrease induced mutations in Ames test was previously revealed for [the] LPS, isolated from a series of strains of $P$. syringae $[6,8]$. Of all the investigated LPS preparations, the biopolymers, studied in this work, demonstrates the least antimutagenic activity, i.e. antimutagenic activity is not the same for LPS, isolated from different strains [6].

Conclusions. LPS of P. syringae pv. atrofaciens 9417 in prokaryotic system do not show any mutagenic activity, on the contrary, they demonstrate antimutagenic activity. LPS do not lead to considerable inhibition of mitotic activity in cells of root apical meristem of onion in the doses below $5.0 \mathrm{mg} / \mathrm{ml}$, which allows us to work with these biopolymers in $A$. серa test. In eukaryotic test-system, LPS of $P$. syringae pv. atrofaciens 9417 have mutagenic effect in the concentrations of 5.0 and $2.5 \mathrm{mg} / \mathrm{ml}$, i.e. the number of fragments increases. Therefore, LPS demonstrate both mutagenic and antimutagenic activity that may be explained by specificities of their interaction with prokaryotic and eukaryotic cells. However, further studies are required to determine the mechanisms of this interaction.

Ю. М. Богдан, Л. М. Буиченко, Л. А. Пасічник, Р. І. Гвоздяк

Вплив ліпополісахариду Pseudomonas syringae pv. atrofaciens 9417 на процеси мутагенезу в про- та еукаріотній системах

Резюме

Мета. Вивчити вплив ліпополісахариду (ЛПС) P. syringae pv. atrofaciens на спонтанні та індуковані мутації в про- та еукаріотній тест-ситемах. Методи. Мутагенну та антимутагенну активність ЛПС вивчали в Allium сера-тесті та тесті Еймса. Результати. ЛПС не впливає на спонтанні мутації у Salmonella typhimurium, але зменшує кількість мутацій, індукованих біхроматом калію та $N$-метил- $N^{\prime}$-нітро- $N$ '-нітрозогуанідином. Під дією ЛПС у концентраціях 10,0 та 5,0 мг/мл знижується мітотичний індекс, а в концентраціях 5,0 та 2,5 мг/мл зростає кількість фрагментів хромосом у клітинах апікальної меристеми корінців А. сера. Висновки. Встановлено різний вплив ЛПС на процеси мутагенезу у клітинах про- та еукаріотів. ЛПС виявляють мутагенну активність в A. сера-тесті та антимутагенну - у тесті Еймса.

Ключові слова: мутації, хромосомні аберачії, ЛПС. 


\section{Ю. Н. Богдан, Л. Н. Буиенкко, Л. А. Пасичник, Р. И. Гвоздяк}

Влияние липополисахарида Pseudomonas syringae pv. atrofaciens 9417 на процессы мутагенеза в про- и эукариотической системах

Резюме

Цель. Изучить вплияние липополисахарида (ЛПС) Рseudomonas syringaе $p v$. на спонтанные и индуцированные мутации в про-и эукариотической тест-системах. Методы. Мутагенную и антимутагенную активность ЛПС изучали в Alliuт сера-тесте и тесте Эймса. Результаты. ЛПС не влияет на спонтанные мутации у Salmonella typhimигіит, но уменьшает количество индуиированных бихроматом калия и $N$-метил$N^{\prime}$-нитро- $N$ '-нитрозогуанидином мутаций. ЛПС в концентрациях 10,0 и 5,0 мг/мл уменьшает митотический индекс, а также в кониентрациях 5,0 и 2,5 мг/мл увеличивает количество фрагментов хромосом в клетках апикальной меристемы корешков А. сера. Выводы. Установлено разное влияние ЛПС на процессы мутагенеза в клетках про- и эукариотов. ЛПС проявляют мутагенную активность в Alliит сера-тесте и антимутагенную - в тесте Эймса.

Ключевые слова: мутации, хромосомные аберрации, ЛПС.

\section{REFERENCES}

1. Varbanets L. D., Zacharova I. Ja., Gvozdjak R. I., Muras V. A. Glykopolymers of Pseudomonas solanacearum and their role in plant infectivity // Mikrob. Zhur.-1989.-51, N 2.P. 25-32.

2. Dow M., Newman M. A., von Roepenack E. The induction and modulation of plant defense responses by bacterial lipopolysaccharides // Annu. Rev. Phytopathol.-2000.-38.-P. 241261.

3. Jakovleva L. M. Role of bacterial glykopolymers in pathogenesis of plant bacterioses // Mikrob. Zhur.-1992.-54, N 3.P. 87-102.

4. Lugtenberg B. J. J., Chin-A-Woegn T. F. C., Bloemberg G. V. Microbe-plant interactions: principles and mechanisms // Antonie van Leeuwenhoek.-2002.-81.-P. 373-383.

5.Vashchenko L. N., Pasichnik L. A., Bogdan Ju. N., Gvozdjak R. I. Antimutagenic activity of the lipopolysaccharide of Pseudomonas syringae pv. syringae UKM V-1027 // Materials of the Int. sci. conf. (1-2 june, 2006, Minsk-Rakov).Minsk, 2006.-P. 68-71.

6. Vashchenko L. M., Pasichnyk L. A., Gvozdyak R. I. Influence of Pseudomonas syringae pv. atrofaciens lipopolysaccharide on spontaneous and induced by bichromate potassium muta- genesis in Salmonella typhimurium // Biopolym. cell.-2004.20, N 4.-P. 295-299.

7. Bogdan Ju. M., Butsenko L. M., Pasichnik L. A., Gvozdjak R. I. Antimutagenic activity of the lipopolysaccharide of Pseudomonas syringae pv. atrofaciens 9400 // Nauk. Visn. Uzhhorod. Univ. (Ser. Biol.).-2008.-24.-P. 110-113.

8. Gvozdyak R. I., Vashenko L. M., Pasichnik L. A. Genoprotektorna aktivnist' lipopolisaharidu Pseudomonas syringae pv. coronafaciens 9030 // Dopov. NAN Ukrainy.-2003.-N 4.P. 159-162.

9. Zacharova I. Ja., Kosenko L. V. Metody izuchenija mikrobnyh polisaharidov.-K.: Nauk. dumka, 1982.-192 p.

10. Fonshtejn L. M., Kalinina L. M., Poluhina G. N., Abilev S. K., Shapiro A. A. Test-sistema otsenki mutagennoy aktivnosti zagryazniteley sredy na Salmonella (Metodicheskie ukazanija).-M., 1977.-P. 1-52.

11. Vashchenko L. M. Mechanism of antimutagenic activity of Pseudomonas syringae lipopolysaccharides // Mikrob. Zhur.-2005.-65, N 2.-P. 30-38.

12. Butsenko L. M. Gene modulation activity of culture liquid and lipopolysaccharide Pseudomonas syringae pv. syringae UKM V-1027 // Nauk. Visn. Uzhhorod. Univ. (Ser. Biol.).2008.-22.-P. 80-83.

13. Rank J. The method of Allium anaphase-telophase chromosome aberration assay // Ekologiya (Vilnius).-2003.-N 1.P. 38-42.

14. Borovikov V. P. Populyarnoe vvedenie v programmu Statistika.-M.: Komp'yuterPress, 1998.-267 p.

15. Bogdan Ju. M., Butsenko L. M., Pasichnik L. A., Gvozdyak R. I. The study of mutagenicity of Pseudomonas syringae pv. atrofaciens 9400 lipopolysaccharide in Allium cepa-testi // Nauk. Zapysky NaUKMA.-2008.-80.-P. 22-26.

16. Gahrton G., Robert K. H., Friberg K., Zech L., Bird A. G. Nonrandom chromosomal aberrations in chronic lymphocytic leukemia revealed by polyclonal B-cell-mitogen stimulation // Blood.-1980.-56, N 4.-P. 640-647.

17. Sewerynek E., Ortiz G. G., Reiter R. J., Pablos M. I., Melchio rri D., Daniels W. M. U. Lipopolysaccharide-induced DNA damage is greatly reduced in rats treated with the pineal hormone melatonin // Mol. and Cell. Endocrinol.-1996.-117, N 2.-P. 183-188.

18. Suliman H. B., Carraway M. S., Piantadosi C. A. Postlipopolysaccharide oxidative damage of mitochondrial dNA // Amer. J. Respirat. and Crit. Care Med.-2003.-167.-P. 570579. 